\title{
Paleogenetic and taphonomic analysis of human bones from Moa, Beirada, and Zé Espinho Sambaquis, Rio de Janeiro, Brazil
}

\author{
Anderson Nonato do Rosario Marinho/ ${ }^{+}$, Newton Cardoso Miranda*, Valéria Braz**, \\ Ândrea Kely Ribeiro-dos-Santos, Sheila Maria Ferraz Mendonça de Souza**
}

\begin{abstract}
Laboratório de Genética Humana e Médica, Departamento de Patologia, Centro de Ciências Biológicas, Universidade Federal do Pará, Av. Augusto Correa 1, 66075-970 Belém, PA, Brasil *Museu Nacional, Universidade Federal do Rio de Janeiro, Rio de Janeiro, RJ, Brasil **Departamento de Endemias Samuel Pessoa, Escola Nacional de Saúde Pública Sergio Arouca-Fiocruz,
\end{abstract} Rio de Janeiro, RJ, Brasil

The present paper discusses mtDNA and taphonomy of human remains from Moa, Beirada, and Zé Espinho sambaquis of Saquarema, state of Rio de Janeiro, Brazil. New human bone dating by ${ }^{14} C$-AMS for Moa archeological site $(3810+50$ BP - GX-31826-AMS) is included. Preservation of microscopic lamellae and DNA is not related to the macroscopic integrity of the bones. Results here suggest that the preservation of amplifiable DNA fragments may have relation to the preservation of the lamellar arrangement as indicated by optical microscopic examination (polarized light). In 13 human bone fragments from Moa, Beirada, and Zé Espinho it was possible to sequence $m t D N A$ from the 3 individuals of Moa, and from 1 of 4 individuals of Beirada, whose bones also show extensive areas with preserved lamellar structures. The 6 human bone fragments of Zé Espinho and 3 of the 4 fragments of Beirada showed extensive destruction of cortical microstructure represented by cavities, intrusive minerals, and agglomerated microscopic bodies of fungi and bacteria; it was not possible to extract mtDNA from these samples. The results support the hypothesis that the preservation of the microscopic osteon organization is a good predictor for DNA preservation. It was also confirmed the C haplogroup antiquity in Brazil.

Key words: paleogenetics - mtDNA - taphonomy - sambaqui - prehistory - ${ }^{14} \mathrm{C}$ dating

The problem of poor preservation of DNA in ancestral samples constitutes one of the main factors for efforts and laboratory investments as it is not possible to obtain biological material in most DNA analysis. The identification of samples with larger probability of yielding aDNA has been investigated by different authors (Handt et al. 2005, Salamon et al. 2005, Gilbert et al. 2005). The relation between the taphonomic changes observed in bones and the successful obtaining of mtDNA in the present work may help to further understand DNA preservation in bones and promotes the innovation of more reliable research protocols.

About $35 \%$ of bone is made up of organic material, of which approximately $90-95 \%$ is collagen. The mineral portion is formed mainly by calcium phosphate in the form of hydroxyapatite (Waldron 1987, Schultz 1997). The organic portion undergoes quick degradation by water and microorganisms present in soil, which decompose it to sub products such as peptides and amino acids (Henderson 1987, Heuck 1993, Schultz 1997). Similarly, the mineral portion of bones undergo intense chemical action and decomposition by microorganism, which enables the substitution by minerals in soil such as $\mathrm{CaCO}_{3}, \mathrm{Fe}_{2} \mathrm{O}_{3}$, and

Financial support: Finep, Capes, CNPq

${ }^{+}$Corresponding author: andersonufpa@yahoo.com.br / akely@ufpa.br

Received 20 July 2006

Accepted 16 October 2006
$\mathrm{SiO}_{2}$, which gradually get into the voids left by hydroxyapatite. Thus, in many cases a mold of the original bone structure (Retallack 1984, Herderson 1987, FrancillonVieillot et al. 1990, Garland 1993) is formed. Even though the macroscopic morphology is maintained, there can be either total or partial substitution of the components at microscopic level with the opening of cavities, deposition of intrusive minerals, growth of microorganisms, and the consequent transformation of the microscopic morphology of the bones, making disappear its original lamellar aspect. This arrangement, identifiable in histological slides of fresh bones, can also be seen in slides of archeological bones with the help of polarized light and roughly serves to verify the effect of the taphonomic processes (Lambert et al. 1979, Francillon-Vieillot et al. 1990, Gilbert 1997, Gill-King 1997).

DNA also undergoes a series of alterations caused by taphonomic processes. Nucleases, enzymes that hydrolyze the DNA molecule, can be present in the corpses themselves or be produced by bacteria and fungi associated to corpse decomposition processes (Bar et al. 1988, Perry et al. 1988, Rogan \& Salvo 1990b). Oxidative damage to the DNA molecule is caused by oxygen free adicals also produced by soil microorganisms. These free radicals, which are extremely reactive because of their nonpaired electrons, break the sugar-phosphate bonds and release the bases that form the nucleic acids and consequently degrade the DNA (Rogan \& Salvo 1990b, Goldenberg 1994). The increase in temperature provokes the break of the hydrogen bonds that bind the two DNA molecule ribbons and may also favor an increase in nuclease activity (Lindahl \& Nyberg 1972, Rogan \& Salvo 1990b). 
Very low $\mathrm{pH}$ can also provoke progressive digestion of the DNA molecule (Lindahl \& Nyberg 1972).

In contrast, although ancient DNA studies may be difficult to carry out (because of sample preservation), they are very important for the discussion of the process of prehistoric occupation of the southeastern coast of Brazil by fishermen-hunters-gatherers, dated from 8000 $\mathrm{BP}$ to $1000 \mathrm{BP}$ (Lima et al. 2004). For genetics to be able to propose microevolutionary models of the coastal settling of Brazil during the prehistoric period, it is necessary to study the aDNA of a large number of individuals of different prehistoric sites to know the genetic variability of these populations and their relation with other populations of the New and the Old Worlds.

In addition the use of DNA analysis for parasite analysis in preserved bones from archaeological sites (Spigelman \& Lemma 1993, Salo et al. 1994) is draining considerable efforts of professionals who believe this could help fulfilling gaps of information concerning the emergence and transmission of infectious diseases. Bones and teeth are good environment to trap and preserve the cells of microorganisms once in the blood stream. The study of histologic as well as biochemical preservation of bone and is of great interest not only for human evolutionary studies but also to paleoparasitology and paleopathology in general.

Samples of human rib bones were collected at three sambaqui sites excavated in the state of Rio de Janeiro. They date relatively close to each other, but exposed to different taphonomic conditions. Bone fragments were submitted to aDNA extraction and to microscopic examination to evaluate the degree of preservation of their ultrastructure. A sample from Moa site was also dated by ${ }^{14} \mathrm{C}$-AMS at Geochron Laboratory, US for chronological confirmation. Femur samples of the same individuals of Moa and Beirada sites had already been analyzed for mi- croscopic preservation by one of the authors, affording the basis of the present study (Braz 2001).

In this paper the initial results are presented and the relation between bone preservation at microscopic level and the possibility of obtaining DNA by the chosen method is discussed.

\section{Saquarema sambaquis and the preservation of ances- tral DNA}

The sambaquis of Saquarema municipality, state of Rio de Janeiro, were inhabited from about 4500 to 1800 years ago. According to Kneip and Machado (1993), the human prehistoric populations traveled along the Saquarema coast and settled close to the sea, where they built sambaquis that served both as dwelling and burial grounds. Among the groups that inhabited Saquarema are the ones that constructed the Moa and Beirada sambaquis. Zé Espinho sambaqui is located at Guaratiba plains and was inhabited between 2200 and 1180 years ago (Kneip 1999). It is placed in mangrove and the lower levels of the site are periodically inundated by tidal effects. Dating of different stratigraphic layers of these sites (Kneip \& Machado 1993, Kneip et al. 1987) is given in Table I.

According to Kneip (1999), the burial practices of Beirada and Moa are similar, including the large number of primary burials in both sites. The two sites also resemble in aspects of their material culture (Kneip \& Machado 1993, Kneip et al. 1994) and they were settled approximately at the same time and may have been early contemporaneous. The Zé Espinho sambaqui was occupied almost 2000 years after Moa and Beirada sites. In all three cases, and despite the distance and chronological differences, weather conditions and the soil of the settlements were similar and common taphonomic factors affecting the skeletonization were shared during the period when the sites were used as dwellings and cemeteries.

TABLE I

Distribution of radiocarbon dating from Moa, Beirada, and Zé Espinho sambaquis. The stratigraphic layers are numbered in ascending order from top to botton at the archaeological sites

\begin{tabular}{lrrrr}
\hline Site & Layer & Date/years BP & Material & Sample \\
\hline Moa & I & $3610 \pm 190^{b}$ & Shell, charcoal & Bah-1762 \\
& 3A & $3810 \pm 50^{a}$ & Human bones & BX31826 \\
Beirada & II & $3960+200^{b}$ & Shell, charcoal & Bah-1765 \\
& I & $3800 \pm 190^{b}$ & Shell, charcoal & Bah-1646 \\
& II & $4160 \pm 180^{b}$ & Shell, charcoal & Bah-1647 \\
Zé Espinho & II & $4300 \pm 190^{b}$ & Shell, charcoal & Bah-1651 \\
Mound A & & $4520 \pm 190^{b}$ & Shell, charcoal & Bah-1339 \\
& & & & Bah-1338 \\
II & II & $1510 \pm 160^{c}$ & Shell, charcoal & Bah-1340 \\
Mound C & III & $1780 \pm 170^{c}$ & Shell, charcoal & Shell, charcoal \\
& I & $1920 \pm 150^{c}$ & Shell, charcoal & Bah-1341 \\
Mound D & I & $1180 \pm 170^{c}$ & Shell, charcoal & Bah-1344 \\
& II & $1650 \pm 170^{c}$ & Shell, charcoal & Bah-1347 \\
\hline
\end{tabular}

$a$ : present study ; $b$ : Kneip et al. (1991); $c$ : Kneip et al. (1987). 
Other differences concerning the physical and chemical layers in which the bodies were buried, as well as the biotic activity in each case may respond for differential preservation between the sites.

Dating based on human bones, charcoal, and shells from the sites of Moa, Beirada, and Zé Espinho with respect to their archeological layers is given in Table I.

Bones are composed of cortical (compact) and trabecular (spongy) bones. Cortical bone is more resistant to decomposition. Collagen is an organic component, while the mineral portion is composed of ionic components such as calcium $\left(\mathrm{Ca}^{+}\right)$, magnesium $\left(\mathrm{Mg}^{+}\right)$, phosphate $\left(\mathrm{PO}^{-}\right)$, carbonate $\left(\mathrm{CO}^{-}\right)$, hydroxyl $\left(\mathrm{OH}^{-}\right)$, chloride $\left(\mathrm{Cl}^{-}\right)$, fluoride $\left(\mathrm{F}^{-}\right)$, citrate $\left(\mathrm{C}_{6} \mathrm{H}_{3} \mathrm{O}_{7}^{3-}\right)$ among others. Calcium phosphate (CaPO4) occurs as a mineral called hydroxyapatite (Astibia et al. 1990). In soil, bone undergoes taphonomic changes, including intense diagenesis, a process in which the original components of the structure are dissolved and gradually substituted by mineral components in soil. Other vertebrate and invertebrate skeletons present in the construction substrate of the sambaquis also undergo diagenesis (Henderson 1987, Bell 1990). In compact bone, it is possible to observe the progressive transformation at macroscopic level more easily as the taphonomic processes take place (Francillon-Vieillot et al. 1990, Mello 1999).

Due to the mineral abundance of the three sambaqui substrates, the fertile soil is favorable to vegetal growth and there is intense bioactivity in the subsoil. These sites are also composed of sandy aerated permeable subsoil which is easily penetrated by rain and flood waters, helping the migration of organic and mineral components, further favoring the bioactivity. In these conditions, the influence taphonomic factors (such as diagenesis, or physical-chemical factors, and modification by plant roots and microorganism) on human bone buried at these sites may have been very intense. In tropical hot and humid climates the materials of archeological sites are therefore subjected to intense percolation and bioactivity for a long period, which actively mobilizes the organic matter and mineral salts (Francillon-Vieillot et al. 1990, Bianco \& Ascenzi 1993, Fernandéz-López 2000). In the three sites the burials were direct and primary.

The Beirada sambaqui is composed of four rather distinct layers of sandy humid soil with characteristic zones of large and small concentration of mollusk shells and areas of combustion and presence of red discoloration (iron oxide powders and as concretions) frequently associated with burials. The bones analyzed in the present paper belong to layer II, which is characterized by the presence of mollusk shells, food remains, and hematite (Kneip \& Pallestrini 1990, Kneip \& Machado 1993). Such burials date from 4000 years ago.

In the Moa sambaqui, besides the presence of shells, food, and combustion structures there are layers of redcolored sediments represented by silty clay and iron rich concretions brought in from the crystalline hillsides of the region. According to Silveira (2001), in both the burial levels the bodies were lying in shallow graves and involved in the red sediments. Above each grave there were lens of shells and a fireplace that burned after the burial helping to seal this less permeable structure. After skeletonization, the bone fragments became incrusted and impregnated by this reddish silt (Kneip 1999, Silveira 2001). The buried bones date from 3800 years ago.

The Zé Espinho sambaqui is a set of five small mounds identified by distinct archeological units called A, B, C, D, E (Kneip 1987). The main stratigraphic components were sand and humic soil rich in charcoal, bones and artifacts with lens of shells here and there. Burials were present in only two levels. The bones found in hill A, layer III and hill D, layer II were tested for this paper. Hill A, layer III was black in color with an outstanding presence of shells in relation to the other hills, and charcoal residues, ashes, and crustacean fragments. Layer II of hill D is similar, with a larger amount of crustacean shells and plant roots (Kneip 1987). The six burials date from 1900 years ago.

\section{MATERIALS AND METHODS}

Because bone size and density are related to the action of decomposing agents on them we chose to study fragments from a single type of bone and from the same anatomical region. Contiguous fragments were used in histological and paleogenetic studies whenever possible. We studied the rib cortical bone because it is easier to observe variations in its preservation and to extract DNA for histological study. We believed that in this material, the state of conservation must show the gradient of taphonomic alterations produced by environmental factors such as the presence of water, $\mathrm{pH}$ or soil acidity, and the presence of biotic agents such as fungi and bacteria (von Endt \& Ortner 1984, Lambert et al. 1985, Boddington 1987, Henderson 1987, Micozzi 1991).

We chose 13 rib bone samples from 13 different individuals (Table II), being 3 from sambaqui Moa, 4 from Beirada, and 6 from Zé Espinho. In the case of Beirada and Moa sambaquis, these samples were taken from the same individuals whose femur slides (Braz 2001) had been previously studied.

Independent and histological studies by the two first

\section{TABLE II}

Human bone samples obtained for aDNA and histological study distributed according to sites and respective layers. The samples from Beirada and Zé Espinho are here identified by the burial number and also by the registration number in the collection of Museu Nacional

\begin{tabular}{llr}
\hline Site & \multicolumn{1}{c}{ Sample } & Layer \\
\hline Zé Espinho & Burial 83-7(MN2057) & III \\
& Burial 83-9(MN2059) & III \\
& Burial 83-10(MN2060) & III \\
& Burial 84-4D(MN2065) & I-II \\
& Burial 84-6D (MN2067) & II \\
& Burial 84-7D (MN2068) & II \\
Moa & Burial 01 & \\
& Burial 17 & \\
Beirada & Burial 19 & II \\
& Burial 2 (MN2024) & II \\
& Burial 13 (MN2035) & II \\
& Burial 14 (MN2036) & II \\
\hline
\end{tabular}


authors (Marinho 2004, Miranda 2004) were done during the Paleopathology Specialization Course (2004) at Escola Nacional de Saúde Pública-Fiocruz, RJ. The paleogenetic analyses were carried out at the Laboratório de Paleo-genética, Universidade Federal do Pará with during the project Paleogenetics and Paleoepidemiology in Amazonian Pre-historical Populations, funded by Finep. The histological study was carried out at the Laboratório de Bioarqueologia do Setor de Antropologia Biológica, Museu Nacional, and at the Departamento de Anatomia, Universidade Federal do Rio de Janeiro. Radiocarbon dating was supported by the aforementioned Finep project.

The histological slides obtained from cortical rib bones were prepared as indicated by Braz (2001), included in EPOXY-type resin (Araldite XGY, 1109 with catalyst HY 951TM, Ciba Geiby Química), submitted to vacuum for 15 min for removal of bubbles, and cured in oven at $40^{\circ} \mathrm{C}$ for $40 \mathrm{~min}$. Later, one of the faces of each block was ground and polished with wet sandpaper 280 and 1200, and fixed to conventional optical microscopy glass slides with cyanoacryclic resin (Super BonderTM, Heckel Loctite). After fixation to the slide, the free face of each block set to the glass slide was ground with wet sandpaper 180, 600, and 1200 . Next, the slides were sealed with Canada balsam for observation in polarized light optical microscope. The samples were analyzed and photographed in an AXIOPLAN (ZEISS-GERMANY) microscope with polarization filter, $200 \mathrm{X}$ enlarment, and $35-\mathrm{mm}$ lenses.

Sequencing of the first region (HVS-I) of mtDNA from the 13 different individuals obtained from the sambaquis Moa, Beirada, and Zé Espinho. aDNA was extracted by the method described by Sambrook et al. (1989) with modifications of the basic protocol. The bone fragment surface was treated with DNA chelant (sodium hypocloride solution, $10 \%)$ and radiated with ultraviolet light $(250 \mathrm{~nm}$ for $5 \mathrm{~min}$ per surface) before use. With the help of a drill, the internal portion of the fragments was powdered and transferred to $15 \mathrm{ml}$ sterile tubes previously radiated with UV. After powdering, the samples were added $2 \mathrm{ml} \mathrm{EDTA}$ (0.5 M, pH 8.0), $200 \mu \mathrm{l}$ of SDS $10 \%$ and incubated at $40^{\circ} \mathrm{C}$ for $24 \mathrm{~h}$ for decalcification and deproteinization.

After $24 \mathrm{~h}$, it was added $200 \mu \mathrm{l}$ of Proteinase-K $(20 \mathrm{mg} /$ $\mathrm{ml}$ ) and the samples were incubated at $50^{\circ} \mathrm{C}$ for $48 \mathrm{~h}$, after which they were submitted to organic extraction with phenol/chloroform according to Sambrook et al. (1989) and successively washed in Centricom 100 columns (Millipore) following the manufacturer's recommendations. The resulting material was stored in freezer until PCR amplification.

Two PCRs were carried out for ancestral material amplification: the first one with the objective of isolating the preserved mtDNA molecules by amplification of the fragment with the DNA target sequence (symmetric PCR) and a second one, internal to the first fragment for amplification of the specific sequence (asymmetric PCR) according to Ribeiro-dos-Santos et al. (1996).

Sequencing samples were purified with enzymes EXOI and SAP (Biolabs UK, Fermentas US) for removal of primers and nucleotides not incorporated along the reaction.
The direct sequencing of mtDNA was carried out in automatic sequencer ABI Prism-377 (Applied Biosystems, US). The methodology used is based on the biochemical synthesis of the DNA chain by the Sanger et al. (1977) method with kit ABI PRISMTM Dye Terminator Cycle Sequencing (Applied Biosystems, US) and the same PCR primers. The nucleotide sequences produced were directly edited with software Sample Manager coupled to ABI 377 DNA Sequencer in Apple Macintosh G3 computer. These sequences were exported to an IBM PC for later analysis with software Chromas v1.4. Additionally, the sequencing analyses were performed in both directions. And all stages were repeated, from the moment of extraction to the resequencing,

\section{RESULTS}

Histological analysis showed differences in microstructure conservation of human bones from the three sambaquis. Moa bones were the best preserved. Paleogenetic analysis showed that the conservation of aDNA was unequal for the three sites resulting in the extraction and analysis of DNA in only 4 samples.

The histological analysis of the Moa samples revealed a higher degree of preservation without expressive destruction by taphonomic agents, possibly because of the the siltic clay cover that may have interfered in the action of microorganisms and other taphonomic agents. Osteon structures and lamellar configuration is preserved in most of the analysed bones (Fig. 1).

The histological analysis of Beirada samples revealed high or total loss of cortical microarchitecture, not being possible to observe the circumferential lamellar morphology typical of cortex osteons. Only some Haversian canals could be identified. It was also possible to observe the presence of calcite crystal deposits in large cavities.

Zé Espinho samples were microscopically similar to Beirada samples, with extensive loss of lamellae. A high degree of morphological destruction and total loss of the microarchitecture are evident in most of the surfaces. Contrary to what is seen in Beirada samples, in Zé Espinho samples it was not possible to observe calcite (Fig. 2).

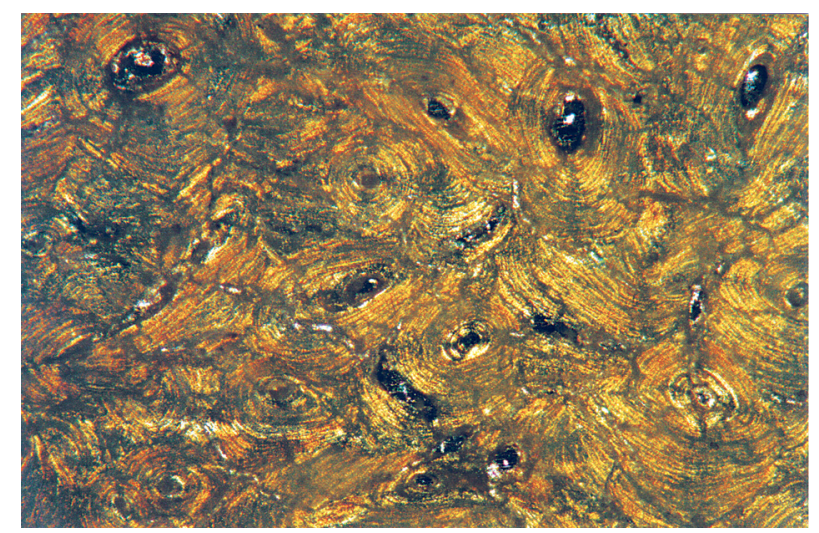

Fig. 1: polarized light photomicrography $(\times 100)$ of a transversal section of rib bone from Moa sambaqui (skeleton \#19). Despite the microfractures, birrefringence is preserved and the osteons can be measured. 
The paleogenetic analysis of the mtDNA present in the samples afforded positive results for 4 out of 13 samples. These including all 3 Moa samples examined (burials 1,17, and 19), and only 1 of the 4 samples of the Beirada sambaqui (burial 22). None of the 6 samples from Zé Espinho were positive for DNA. Also for burial 17 from Moa, a date of $3810+50 \mathrm{BP}$ (GX-31826-MAS, $13 \mathrm{C}$ corrected) was obtained.

Sequencing was carried out by automatic reading of electropherogram peaks obtained after the end of electrophoresis in an automatic sequencer and by manual comparison with the reference sequence described by Anderson et al. (1981). We observed a total of 22 distinct punctual mutations that defined four haplotypes, three in the Moa sambaqui and one in Beirada. All mutations observed were transition-type; 10 presented pattern $\mathrm{C} \rightarrow \mathrm{T}, 11$ with $\mathrm{T} \rightarrow \mathrm{C}$ and a single pattern $\mathrm{A} \rightarrow \mathrm{G}$ (Table III).

The results of the analysis of the set of mutations observed in these two sambaquis were compared to those previously reported by Horai et al. (1993); Santos et al. (1996); Ribeiro-dos-Santos et al. (1996); Kolman et al. (1996); Lorenz and Smith (1996, 1997); Stone and Stone-

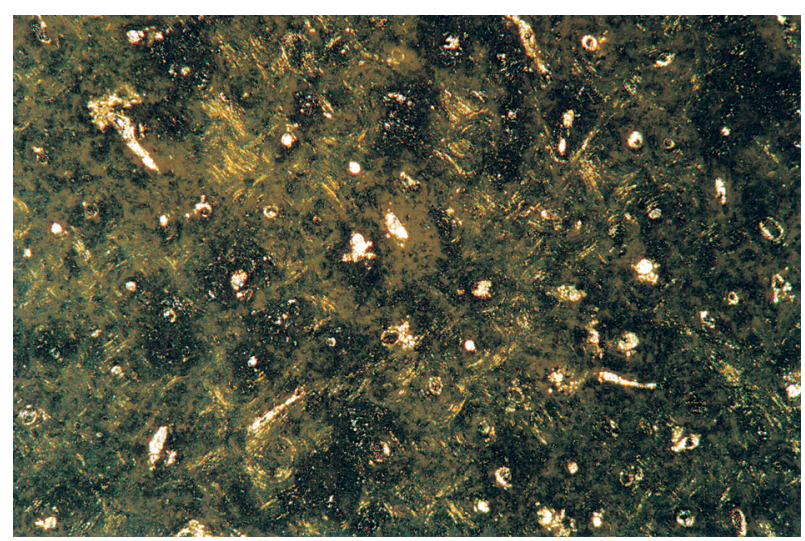

Fig. 2: polarized light photomicrography $(\times 50)$ of a transversal section of rib bone from Zé Espinho sambaqui (MN 2067, layer II), showing that birefringence is not preserved in most parts of the histological section. king (1998); Lalueza-Fox et al. (2001, 2003); Malhi et al. (2001); Yao et al. (2002); Bolnick and Smith (2003); Torres et al. (2006). It was possible to classify these mutations as belonging to haplogroup $\mathrm{C}$.

After alignment of the sequences with software ClustalX (Thompson et al. 1997) and analysis by Nucleotide Sequence Comparison Program - MEGA (Saitou \& Nei 1987), a phylogenetic tree of the samples of Moa (burials 1,17 , and 19) and of Beirada sambaquis (burial 22), was obtained. Through this analysis, it was possible to observe that two burials ( 17 of Moa and 22 of Beirada) share the same group of mutations and that they are closely related with burial 19 of Moa, while burial 1 of Moa is the most basal of all four analyzed (Fig. 3).

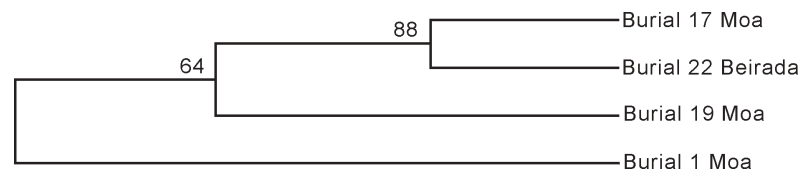

Fig. 3: phylogenetic tree of the skeletons from Moa (burials 1, 17, and 19) and Beirada sambaquis (burial 22), neighbor-joining method by Nucleotide Sequence Comparison Program - MEGA (Saitou \& Nei 1987). The genetic and the chronological proximity, of samples suggest relationship between the two prehistoric groups.

\section{DISCUSSION}

The rib bone cortical fragments examined in the present paper show varying degrees of preservation. The microscopic architecture of Moa sambaqui bones was the best preserved compared to those from Beirada and Zé Espinho which presented either partial or total loss of microscopic architecture. As previously described for femur samples of the same archaeological site (Braz 2001), the lamellae and osteonic organization in the cortical bone could only be extensively detected in Moa sambaqui samples. The preservation of the ultrastructural aspects of the bone and the positive result for DNA extraction were related. It was impossible to obtain DNA from those samples with poor preserved ultrastructures.

TABLE III

Sequences of the D-loop of mtDNA identified in human bones of Moa and Beirada sambaquis, Saquarema, RJ. The position of the nucleotides (added with number 16,000) in the DNA molecule is presented in the first line followed by the reference sequence of Anderson et al. (1981), shown on the second line. The mutation represented in bold define the four haplotypes indicated in the first column

\begin{tabular}{|c|c|c|c|c|c|c|c|c|c|c|}
\hline \multirow{5}{*}{ mtDNA Mutation Points } & 1 & 1 & 1 & 1 & 1 & 1 & 1 & 1 & 1 & \multirow{5}{*}{ 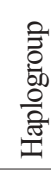 } \\
\hline & 6 & 6 & 6 & 6 & 6 & 6 & 6 & 6 & 6 & \\
\hline & 0 & 1 & 2 & 2 & 2 & 2 & 3 & 3 & 3 & \\
\hline & 5 & 3 & 2 & 4 & 9 & 9 & 2 & 2 & 6 & \\
\hline & 1 & 6 & 3 & 2 & 2 & 8 & 5 & 7 & 2 & \\
\hline Reference sequence Anderson et al. (1981) & A & $\mathrm{T}$ & $\mathrm{C}$ & $\mathrm{C}$ & $\mathrm{C}$ & $\mathrm{T}$ & $\mathrm{T}$ & $\mathrm{C}$ & $\mathrm{T}$ & \\
\hline Burial 1 - Moa & & $\cdot$ & $\mathrm{T}$ & . & & $\mathrm{C}$ & $\mathrm{C}$ & $\mathrm{T}$ & & $\mathrm{C}$ \\
\hline Burial 17 - Moa & . & . & $\mathrm{T}$ & 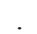 & $\mathrm{T}$ & $\mathrm{C}$ & $\mathrm{C}$ & $\mathrm{T}$ & $\mathrm{C}$ & $\mathrm{C}$ \\
\hline Burial 19 - Moa & G & $\mathrm{C}$ & $\mathrm{T}$ & $\mathrm{T}$ & . & $\mathrm{C}$ & $\mathrm{C}$ & $\mathrm{T}$ & . & $\mathrm{C}$ \\
\hline Burial 22 - Beirada & & . & $\mathrm{T}$ & . & . & $\mathrm{C}$ & $\mathrm{C}$ & $\mathrm{T}$ & $\mathrm{C}$ & $\mathrm{C}$ \\
\hline
\end{tabular}


Femur cortical fragments of the same skeletons previously analyzed by Braz (2001) also showed that Beirada sambaqui samples lost lamellar organization in different grades, but the destruction was more pronounced in samples from layer I (top) when compared to layer III (bottom). In contrast, Moa samples presented an excellent degree of microscopic conservation for femur samples. The limited number of samples tested in the present paper did not allow testing DNA conservation and preservation of rib bones from different layers of the Beirada sambaqui.

Yet in the previous work of Braz (2001), the use of electron microscopy allowed observations of microcavities that were interpreted as resulting from the action of microorganisms (Piepenbrink 1984, Schultz 1986). The same cavities were not observed in Moa samples. This fact reinforces the interpretation that the bioactivity possibly associated to progressive demineralization destroyed the lamellar structure exposing and destructing DNA in archeological bones. This process seems to be independent of the cristalization of calcite inside the harversian systems that can be seen more frequently in bones from Beirada (which layers are rich in shells) and less frequently in bones from Zé Espinho.

The poor conservation of genetic material of Beirada sambaqui is possibly due to the combination of a series of factors. That sambaqui is covered by restinga vegetation (Kneip 1999), which affords the proliferation of soil microorganisms, including fungi and bacteria that actively degrade the internal structure of bones, specialy at the upper levels. Their action on DNA may be explained by mechanical effect of the digestive activity on the microarchitecture of the bones, exposing even the DNA inside the microcristaline aggregates (Salamon et al. 1995) and the continuous production of free oxygen radicals as a sub product of their metabolisms, and the production of enzymes able to hydrolyze DNA (Perry et al. 1988, Rogan \& Salvo 1990a).

Contrary to Beirada samples, Moa bone samples were better preserved and were positive for genetic material in the three tested samples (burial 1, burial 17, and burial 19). The excellent standard of conservation for DNA of Moa sambaqui skeletons is associated here to a significant preservation of the cortical microstructure. In her previous XRD analysis of Moa femur samples Braz (2001) confirmed a higher indice of crystalinity (for hydroxyapatite) when compared to Beirada samples. This observation is consistent with the preservation of microcrystalline arrangements and preservation of the lamellar microarchitecture. Indeed, both the morphological and physicalchemical confirmations of the presence of the organic microcrystalline structure in Moa bone samples are here predictive of better DNA preservation as described by Salamon et al. (2005).

In Zé Espinho sambaqui the skeletons were buried in layers of black soil rich in organic compounds and few shells. Surrounded by mangrove the site was continuously affected by tidal effects bringing salt waters close to the sambaqui, keeping higher humidity levels at the archaeological layers, and promoting biotic activity and chemical degradation. The scarcity of calcite in the Harversian systems is coherent with the low availability of calcium minerals in the archaeological layers, and in the bones as well. Intense biotic activity is predicted to be present in all levels equally affecting the different mounds and skeletons. In fact the results for 6 different skeletons were poor ultrastructural preservation and no DNA at all, despite the fact that Zé Espinho burials studied here (mound A, layer III and mound D, layer II) are about 2000 years younger than the burials in Moa and Beirada.

Compared to the Moa bones, the Beirada bones are not so well preserved, although the concentration of shells in the archaeological layers of Beirada mean more free minerals and alkalinity usually associated to better preservation. The skeletons from Beirada layer II (upper level) studied in the present paper are supposed to have been more intensely washed by percolating water and exposed to the humic soils where roots and biota afford the acidity necessary for the dissolution of minerals. Differential preservation observed in Beirada, where some bones were better preserved than other, is possibly associated to local factors, and because of this it was possible to recover DNA in 1 individual. Certainly the great amount of shell in the site helped protecting part of the bones from more intense degradation.

Moa sambaqui is not far from Beirada, has less accumulation of archaeological layers and lens of shells instead of the dense accumulation of shells found in Beirada. Restinga vegetation and bioactivity was certainly present on this site for millennia and the shallow archaeological deposits left the burials close to the surface, for almost the same period than the Beirada's were exposed to taphonomic factors. On the other side, at Moa sambaqui there is a cultural peculiarity that is absent in the other two sambaquis: the presence of red soil layers build up by humans with clay from the hills far from the coast. Layers surrounding the buried bodies are formed by less permeable rock that possibly modulated the taphonomic processes. A true shell of incrustation still difficult to remove from the bones was an additional problem for laboratory analysis. This incrustation has been isolating the bones from the environment for thousands of years since the skeletonization was complete. Previous microscopic examination of Moa femural bones (Braz 2001) showed little cavities, preservation of the crystalline architecture, and no sign of significant microbial proliferation. It is possible to argue that the bone decomposition process that occurs naturally in the soil was stopped at the skeletonization stage under the protection afforded by this red clay used in the burial ritual. This can be especially true if we consider that the mollusk shells in the archeological layers of Moa were mainly on the burial places, and partially cemented by a fireplace, capping the grave. Chemical protection, less humidity and less biotic activity seems to have been the conditions for those skeletons, where microstructure and DNA inside the bones were preserved as a consequence.

Despite the apparent macroscopic preservation of the bones, the microscopic analysis for ribs as well as for femurs (Braz 2001), point to the problem that microorganisms inside the cavities inside the cortical bone can be responsible for the advanced destruction of human DNA. 
The same taphonomic change must be considered for the destruction of parasitic DNA inside the vascular channels and other soft tissue spaces inside the bones. More than destroying, the microorganisms responsible for the bone decay bring contaminant DNA of different origins that certainly act as confounders to the analysis. Because of this parasitic DNA in many cases may be very easy to find but not conclusive about infection during lifetime. Natural bioactivity from the environment involving different environmental microorganisms produce a huge number of small and unknown DNA fractions inside the sample, some of them may be similar to the DNA one is searching for. The results presented in this paper can also help to understand the taphonomic processes involved in bone changes in the soils and its consequences for the studies of infectious diseases based in DNA, as well as helping to understand the positive and/or negative results in human DNA sampling.

Thanks to the differential preservation in the three sites it is also possible to drawn the first comments on the possible microevolution process of the three individuals of Moa and of one of Beirada whose DNA was studied here. As a result of the phylogenetic analysis of the mitochondrial DNA sequences, it was possible to observe a close relation between the mutations present in the two burials (burial 17 from Moa, burial 22 from Beirada). It is possible to propose a genetic proximity between the two individuals, although they belong to distinct sambaquis. The close $\mathrm{C}^{14}$ dates for both sites suggest contemporaneity, as well as similar cultural aspects such as diet and burial practices (Kneip 1999). The concentration of sambaqui sites in Saquarema neighbourhood and their chronology suggest that one genetic population occupied the region during that period, reinforcing the interpretation of our results.

The three sambaqui individuals whose DNA was studied in the present paper were buried in Saquarema, RJ between 3800 to $4000 \mathrm{BP}$, belonging to the haplogroup C. This haplogroup was described for contemporaneous Amerindian populations (Torroni et al. 1992, 1993a, b, Horai et al. 1993, Santos et al. 1996, Kolman et al. 1996, Lorenz \& Smith 1996, 1997, Malhi et al. 2001, Yao et al. 2002, Bolnick $\&$ Smith 2003, Torres et al. 2006) and for pre-Columbian populations of the America (Ribeiro-dos-Santos et al. 1996; Stone \& Stoneking 1998, Lalueza-Fox et al. 2001, 2003). About $22 \%$ of the samples studied for prehistoric and contemporaneous Brazilian Indians belong to thar haplogroup. Among the samples that presented the earliest chronological dates (4000 BP) there were also the haplogroups I (B), III (A), IV (C), and two atypical to group $\mathrm{V}$, with at least one belonging to haplogroup $\mathrm{C}$ (Ribeirodos-Santos et al. 1996).

The comparison of the contemporaneous individual of haplogroup $\mathrm{C}$ (corresponding to IV) to the ones found in Moa and Beirada skeletal samples suggest that this haplogroup was largely distributed in the past, ranging from the Amazon region to the southeastern coast of Brazil. Therefore, haplogroup $\mathrm{C}$ can represent one of the most frequent ancestral haplogroups in the second migratory wave of these peoples.

\section{Conclusion}

The study of human rib bone samples from 13 skeletons from the Moa, Beirada, and Zé Espinho sambaquis strongly suggest that the preservation of DNA in archaeological bones can be directly associated to the preservation of the crystalline microstructure expressed in the lamellar arrangement of cortical bone. The hypothesis presented here is that the better the microscopic architecture is preserved, the higher the probability that the DNA has been preserved.

The microscopic as well as DNA preservation in the human bones studied in the present paper had apparently no relationship with the amount of shells in the sambaquis or the antiquity of the burials, but instead, with the protection/exposure to humidity and bioactivity. In this way, the best preserved remains were from Moa sambaqui which 3 samples provided DNA extraction; Beirada sambaqui had differential preservation and 1 in 4 samples provided DNA; and Zé Espinho, although the less ancient site, had the worst preservation both histologically and for DNA, as far as the 6 studied samples had destroyed microstructure and provided no DNA.

The 4 skeletons providing DNA belonged to the same haplogroup, C, what is coherent with previous studies suggesting this is one of the founding haplogroups of the pre-Columbian populations.

Future studies with different techniques and enlarged samples must be done to confirm the interpretations proposed here.

\section{ACKNOLEDGEMENTS}

To Dr Claudia Rodriguez-Carvalho, Bioarcheology Sector, Department of Anthropology, Museu Nacional, and also Dr Adilson Salles, Department of Anatomy, both from UFRJ, for the use of the laboratories in their departments during the analysis.

\section{REFERENCES}

Anderson S, Bankier AT, Barrel BG, De Bruijn MH, Coulson AR, Drouin J, Eperon IC, Nierlich DP, Roe BA, Sanger F 1981. Sequence and organization of the human mitochondrial genome. Nature 290: 457-465.

Astibia H, Herrero JM, Elorza JJ 1990. An example of petrographic microscopy and x-ray difraction tecniques as tools in vertebrate taphonomic analysis of some spanish fossil material. In S Fernandez, Comunicaciones Reunión Tafonomía y Fosilizacion, Universidad Complutense Madrid, Madrid, p. 27-39.

Bar W, Kratzer A, Machler M, Schmid W 1988. Postmortem stability of DNA. Forensic Sci Int 4: 150-162.

Bell LS 1990. Paleopathology and diagenesis: a SEM evaluation of structural changes using backscattered electron imaging. J Archaeol Sci 17: 85-102.

Bianco P, Ascenzi A 1993. Paleopathology of human bone remains: a critical evaluation and an example of its use. In $\mathrm{G}$ Grupe, AN Garland (eds), Histology of Ancient Human Bone: Methods and Diagnosis, Springer-Verlag, Berlin, p. 157169.

Boddington A 1987. Chaos, disturbance and decay in an AngloSaxon cemetery. In A Boddington, AN Garland, RC Janaway 
(eds), Death, Decay and Reconstruction: Approaches to Archaeology and Forensic Science, Manchester University, Manchester, p. 27-42.

Bolnick DA, Smith DG 2003. Unexpected patterns of mitochondrial DNA variation among Native Americans from the Southeastern United States. Am J Phys Anthropol 122: 336354.

Braz VS 2001. Estudo dos Processos Tafonômicos em Restos Esqueléticos nos Sambaquis de Beirada e Moa, Saquarema $(R J)$, MSc Thesis, UFRJ, Rio de Janeiro, 75 pp.

Fernandéz-López S 2000. Temas de Tafonomia, Universidad Complutense de Madrid, Madrid, 167 pp.

Francillon-Veilliellot H, Buffrénil V, Castanet J, Géraudie J, Meunier FJ, Sire JY, Zylberberg L, Ricqules A 1990. Microstructure and mineralization of vertebrate skeletal tissues. In JG Carter, Skeletal Biomineralization: Patterns, Processes, and Evolutionary Trends (I), Van Nostrand Reinhold, New York, p. 479-480.

Garland AN 1993. An introduction to the histology of exhumed mineralized tissue. In G Grup, AN Garland (eds), Histology of Ancient Human Bone: Methods and Diagnosis, Springer-Verlag, New York, p. 1-16.

Gilber RI 1997. Applications of trace element research to problems in archaeology. In RL Blakey, Biocultural Adaptation in Prehistoric America, University of Georgia Press, Athens, p. 85-100.

Gilbert MTP, Shapiro B, Drummond A, Cooper A 2005. Postmortem DNA damage hotspots in bison (Bison bison) provide evidence for both damage and mutational hotspots in human mitochondrial DNA. J Archeol Sci 32: 1053-1060.

Gill-King H 1997. Chemical and ultrastructural aspects of decomposition. In WD Haglund, MH Sorg (eds), Forensic Taphonomy: the Postmortem Fate of Human Remains, CRC Press, Boca Raton, p. 93-104.

Goldemberg EM 1994. DNA from plant compression of fossils. In B Herman, S Hummel (eds), Ancient DNA, Springer Verlag, New York, p. 237-256.

Handt O, Krings M, Pääbo S 2005. Ancient DNA: methodological challenges. Experentia 50: 524-529.

Henderson J 1987. Factors determining the state of preservation of human remains. In A Boddington, AN Garland, RC Janaway (eds), Death, Decay and Reconstruction: Approaches to Archaeology and Forensic Science, Manchester University, Manchester, p. 43-54.

Heuck FW 1993. Comparative histological and microradiographic investigations of human bone. In G Grup, AN Garland (eds), Histology of Ancient Human Bone: Methods and Diagnosis, Spring-Verlag, Berlin, p. 125-136.

Horai S, Kondo R, Nakagawa-Hattori Y, Hayashi S, Sonoda S, Tajima K 1993. Peopling of the Americas, founded by four major lineages of Mitochondrial DNA. Mol Biol Evol 10: 23-47.

Kneip LM 1999. Pré-história de Saquarema, RJ. In MC Tenório, Pré-história de Terra Brasilis, UFRJ, Rio de Janeiro, p. 223-232.

Kneip LM, Machado LC 1993. Os Ritos Funerários das Populações Pré-históricas de Saquarema, RJ: Sambaquis da Beirada, Moa e Pontinha (Documento de Trabalho 1,
Série Arqueologia), Museu Nacional UFRJ, Rio de Janeiro, p. 1-76.

Kneip LM, Pallestrini L 1990. O Sambaqui da Beirada à luz da metodologia por superfícies amplas - Saquarema, Rio de Janeiro. Dédalo 28: 171-193.

Kneip LM, Araújo DSD, Fonseca VS 1994. Áreas de Exploração de Recursos Abióticos e Bióticos das Populações Préhistóricas de Saquarema, RJ (Documento de Trabalho 2 Série Arqueologia), Museu Nacional UFRJ, Rio de Janeiro, p. 3-12.

Kneip LM, Ferreira AMM, Oliveira MV, Araújo DSD, Pallestrini L, Chiara P, Crâncio F, Aguiar NVO, Oliveira DV, Samis A, Mello BEM, Correa MMG, Zwink K, Brum INS, Volgel MAC 1987. Coletores e Pescadores Pré-Históricos de Guaratiba, Rio de Janeiro (Série Livros V), Museu Nacional UFRJ, Rio de Janeiro, 257 pp.

Kneip LM, Pallestrini L, Crâncio F, Machado LMC 1991. As estruturas e suas interrelações em sítios de pescadorescoletores pré-históricos do litoral de Saquarema, RJ. Bol I Arqueol Brasileira (Serie Ensaios) 5: 1-42.

Kolman CJ, Sambuughin N, Bermingham E 1996. Mitochondrial DNA analysis of Mongolian populations and implications for the origin of new world founders. Genetics 142: 1321-1334.

Lambert JB, Simpsom SV, Szupunar CB, Buikstra JE 1985. Bone diagenesis and dietary analysis. J Hum Evol 14: 477-482

Lambert JB, Szpunar CB, Buikstra JE 1979. Chemical analysis of excaved human bone from middle and late Woodland sites. Archaeometry 21:115-129.

Lima TA, Macario KD, Anjos RM, Gomes PRS, Coimbra MM, Elmore D 2004. The earliest shellmounds of the Centralsouth Brazilian coast. Nuclear Instruments and Methods in Physics Research - Beam Interactions with Materials and Atoms 223: 691-694.

LindahI T, Nyberg B 1972. Rate of depurination of native deoxyribonuceic acid. Biochemistry 11: 3610-3617.

Lalueza-Fox C, Calderón FL, Calafell F, Morera B, Bertranpetit $\mathrm{J}$ 2001. mtDNA from extinct Tainos and the peopling of the Caribbean. Ann Hum Genet 65: 137-151.

Lalueza-Fox, Gilbert MTP, Martínez-Fuentes AJ, Calafell F, Bertranpetit J 2003. Mitochondrial DNA from preColumbian Ciboneys from Cuba and the prehistoric colonization of the Caribbean. Am J Phys Anthropol 121: 97-108.

Lorenz JG, Smith DG 1996. Distribution of four founding mtDNA haplogroups among Native North Americans. Am J Phys Anthropol 101: 307-323.

Lorenz JG, Smith DG 1997. Distribution of sequence variation in the mtDNA control region of Native North Americans. Hum Biol 69: 749-76.

Malhi RS, Schultz BA, Smith DG 2001. Distribution of mitochondrial DNA lineages among Native American tribes of Northeastern North America. Hum Biol 73: 17-55.

Marinho ANR 2004. Análise do mtDNA e Comparação com o Padrão de Preservação em Restos Esqueléticos dos Sambaquis de Moa e Beirada, Saquarema, RJ, Monography, Escola Nacional de Saúde Pública, Rio de Janeiro, 47 pp.

Mello MGS 1999. Sistematização de Critérios para Diagnóstico 
Diferencial entre Paleopatologias e Alterações Análogas: Fundamentos Teórico-metodológicos, PhD Thesis, Escola Nacional de Saúde Pública, Rio de Janeiro, 212 pp.

Micozzi MS 1991. Postmortem Change in Human and Animal Remais: a Systematic Approach, CC Thomas, Springfield, $126 \mathrm{pp}$.

Miranda NC 2004. Estudo Morfológico das Alterações Postmortem em Remanescentes Esqueléticos de Três Sítios Arqueológicos do Estado do Rio de Janeiro, Monography, Escola Nacional de Saúde Pública, Rio de Janeiro, 27 pp.

Perry WL, Bass WM, Riggsby WS, Sirotkin K 1988. The autodegradation of deoxyribonucleic acid (DNA) in human rib bone and its relationship to the time interval since death. J Forensic Sci 33: 144-153.

Piepenbrink H 1984. Beispiele biogener decompositionserscheinugen an knochen unter längerer liegezeit. Anthropol Anz 42: 241-251.

Retallack GJ 1984. Completeness of the rock region and fossil record: some estimates using fossil soils. Paleobiology 10: $59-78$.

Ribeiro-dos-Santos AKC, Santos SEB, Machado AL, Guapindaia V, Zago MA 1996. Heterogeneity of mitochondrial DNA haplotypes in pre-columbian natives of the amazon. Am J Phys Anthropol 101: 29-37.

Rogan PK, Salvo JJ 1990a. Molecular genetics of Pré-columbian South American mummies. UCLA Symposium in Molecular Evolution 122: 223-234.

Rogan PK, Salvo JJ 1990b. Study of nucleic acid isolated from ancient remains. Yearbook Phys Anthropol 33: 195-214.

Saitou N, Nei M 1987. The neighbor-joining method: a new method for reconstructing phylogenetic trees. Mol Biol Evol 4: 406-425.

Salamon M, Tuross N, Arensburg B, Weiner S 2005. Relatively well preserved DNA is present in the crystal aggregates of fossil bones. PNAS 102: 13783-13788.

Salo WL, Aufderheide AC, Buikstra J, Holcomb TA 1994. Identification of mycobacterium tuberculosis dna in a precolumbian peruvian mummy. Proc Nat Acad Sci USA 91: 2091-2094.

Sambrook J, Fritsch EF, Maniatis T 1989. Molecular Cloning: a Laboratory Manual, 2nd ed., Cold Spring Harbor Laboratory, New York, $88 \mathrm{pp}$.

Sanger F, Nichelen S, Coulson AR 1977. DNA sequences with chain termination inhibitors. Proc Natl Acad Sci USA 74: 5463-5468.

Santos SEB, Ribeiro-dos-Santos AKC, Meyer D, Zago MA 1996. Multiple founder haplotypes of mitochondrial DNA in Amerindians revealed by RFLP and sequencing. Ann Hum Genet 60: 305-319.

Schultz M 1986. Die Mikroskopiche Untersuchung Prähistoricher Skeletfund: Anwendung und Ausagemöglichkeiten der Differentialdiagnostischen Unter-suchung in der Paläopathologie (Archaeologie und Museum 6), Amt für Museen and Archäeologie Baselland, Liestal, 140 pp.

Schultz M 1997. Microscopic investigation of excaveted skeletal remains: a contribution to paleopathology and forensic medicine. In WD Haglund, MH Sorg (eds), Forensic Taphonomy: the Postmortem Fate of Human Remains, CRC Press, Boca Raton, p. 201-222.

Silveira MI 2001. Você é o que Você Come. Aspectos da Subsistência no Sambaqui do Moa-Saquarema, RJ, PhD Thesis, Faculdade de Filosofia, Ciências e Letras USP, São Paulo, $136 \mathrm{pp}$.

Spigelman M, Lemma E 1993. The use of polymerase chain reaction to detect mycobacterium tuberculosis DNA in ancient skeletons. Int J Osteoarchaeol 3: 137-143.

Stone AC, Stoneking M 1998. Ancient DNA from a preColumbian Amerindian population. Am J Phys Anthropol 92: 463-471.

Thompson JD, Gibson TJ, Plewniak F, Jeanmougin F, Higgins DG 1997. The clustal X windows interface: flexible strategies for multiple sequence alignment aided by quality analysis tools. Nucleic Acids Res 24: 4876-4882.

Torres MM, Bravi CM, Bortolini MC, Duque C, CallegariJacques S, Ortiz D, Bedoya G, Groot de Restrepo H, RuizLinares A 2006. A revertant of the major founder Native American haplogroup C common in populations from northern South America. Am J Hum Biol 18: 59-65.

Torroni A, Sukernik RI, Schurr TG, Starikovskaya YB, Cabell MF, Crawford MH, Comuzzie AG, Wallace DC 1993a. mtDNA variation of aboriginal Siberians reveals distinct genetic affinities with native Americans. Am J Hum Genetics 53: 591-608.

Torroni A, Schurr TG, Cabell MF, Brown MD, Neel JV, Larsen M, Smith DG, Vullo CM, Wallace DC 1993b. Asian affinities and continental radiation of the four founding native American mtDNAs. Am J Hum Genetics 53: 563-590.

Torroni A, Schurr TG, Young CC, Szathmary EJE, Williams RC, Schanfield DMS, Troup GA, Knowler WC, Lawrence DN, Weiss KM, Wallace DC 1992. Native American mitochondrial DNA analises indicates that Amerind and the Nadene populations were founded by two independent migrations. Genetics 130: 153-162.

von Endt DW, Ortner DJ 1984. Experimental effects of bone size and temperature on bone diagenesis. J Archaeol Sci 11: $247-253$.

Waldron T 1987. The relative survival of the human skeleton: implications for paleopathology. In A Boddington, AN Garland, RC Janaway (eds), Death, Decay and Reconstruction: Approaches to Archaeology and Forensic Science, Manchester University Press, Manchester, p. 55-64.

Yao Y-G, Kong Q-P, Bandelt HJ, Kivisild T 2002. Phylogeographic differention of mitochondrial DNA in Han Chinese. Am J Hum Genetics 70: 635-651. 
